\title{
The Effect of Cations on Zoospores of the Fungus Phytophthora cinnamomi
}

\author{
By PAULINE N. BYRT, HELEN R. IRVING AND BRUCE R. GRANT* \\ The Russell Grimwade School of Biochemistry, University of Melbourne, Parkville, \\ Victoria 3052, Australia
}

(Received 10 August 1981; revised 24 September 1981)

\begin{abstract}
Swimming zoospores of the fungus Phytophthora cinnamomi exposed to a range of ions were much more sensitive to cations than anions. One cation, $\mathrm{Ca}^{2+}$, induced zoospores to encyst and subsequently germinate, but most cations induced encystment only and were toxic at higher concentrations. In general, the sensitivity of zoospores to a cation increased with its charge density. At $0.3 \mu \mathrm{M}, \mathrm{La}^{3+}$ reduced the viability of a zoospore population to $50 \%$, while $\mathrm{Fe}^{3+}(20 \mu \mathrm{M})$ and $\mathrm{Mn}^{2+}(50 \mu \mathrm{M})$ induced encystment with only a slight decrease in viability. The other divalent and monovalent cations tested $\left(\mathrm{Mg}^{2+}, \mathrm{Ca}^{2+}, \mathrm{Ba}^{2+}, \mathrm{Li}^{+}, \mathrm{Na}^{+}, \mathrm{K}^{+}, \mathrm{Cs}^{+}\right.$, $\mathrm{NH}_{4}^{+}$) were effective in inducing encystment or reducing viability at higher concentrations. Each ion showed a distinctive concentration-response curve. Only $\mathrm{F}^{-}$and $\mathrm{CH}_{3} \mathrm{COO}^{-}$among the anions tested $\left(\mathrm{Cl}^{-}, \mathrm{NO}_{3}{ }^{-}, \mathrm{F}^{-}, \mathrm{H}_{2} \mathrm{PO}_{4}{ }^{2-}, \mathrm{SO}_{4}{ }^{2-}, \mathrm{CH}_{3} \mathrm{COO}^{-}\right)$had any effect on zoospores, and at $20 \mathrm{mM}(\mathrm{pH} \mathrm{6.0)}$ they reduced viability.

The cysts (cystospores) of the fungus were generally less sensitive to cations than were swimming zoospores, and only $\mathrm{Cs}^{+}$and $\mathrm{K}^{+}(50 \mathrm{~mm})$ reduced viability to the same extent in each population. Both zoospores and cysts of this fungus had a broad tolerance to $\mathrm{pH}$ and temperature, but cysts were more resistant to low temperatures than were motile zoospores.
\end{abstract}

\section{INTRODUCTION}

The biflagellate zoospores of the Oomycetes go through the process of cyst (cystospore) formation and cyst germination after their release from sporangia and before the formation of a new mycelial state. The changes in ultrastructure during this transformation have been described for a variety of species and genera (see Lunney \& Bland, 1976). The details of the ultrastructural changes during the process of cyst formation and germination have been well documented in the genus Phytophthora (Hemmes \& Hohl, 1971; Tokunaga \& BartnickiGarcia, 1971; Bimpong \& Hickman, 1975; Sing \& Bartnicki-Garcia, 1975). However, there is less information on the mechanisms which trigger these developmental changes.

The external ionic environment affects zoospore differentiation in both the monoflagellate Blastocladiella emersonii and the biflagellate Aphanomyces astaci (Soll \& Sonneborn, 1972; Svensson \& Unestam, 1975). There are indications that Phytophthora zoospores are similarly affected since the motility of Phytophthora palmivora (Butl.) Butl. is reduced by $\mathrm{Ca}^{2+}$ and $\mathrm{Mg}^{2+}$ salts (Bimpong \& Clerk, 1970). In addition, $P$. palmivora zoospores exhibit negative chemotaxis in response to a range of cations (Cameron \& Carlile, 1980). In the case of the plant pathogen Phytophthora cinnamomi Rands, zoospores are repelled by inorganic cations (Allen \& Harvey, 1974), and there is evidence that the disease pattern is influenced by soil cation levels (Broadbent \& Baker, 1974; Halstall \& Forrester, 1977; Boughton et al., 1978).

We show here that in $P$. cinnamomi the transformation of swimming zoospores to germinating cysts is affected by the external concentration of cations and suggest that specific ion effects are involved rather than changes in osmotic pressure. The significance of the 
results in relation to the potential behaviour of the parasite in soil and its capacity to act as a pathogen is discussed.

\section{METHODS}

The isolate of $P$. cinnamomi (A-2 compatibility type) was obtained from the Brisbane Ranges, Victoria, by Dr G. Weste and designated by her as isolate PC110 (Commonwealth Mycological Institute Collection, IMI 252489). Zoosporangia were induced and zoospores released from axenic cultures as described previously (Byrt \& Grant, 1979). After release the zoospores $\left(10^{4}-10^{5}\right.$ cells $\left.\mathrm{ml}^{-1}\right)$ were held in Tris-succinate buffer, $\mathrm{pH} 6 \cdot 5(1 \mathrm{mM})$ at $16 \pm$ $1{ }^{\circ} \mathrm{C}$ and used within $2 \mathrm{~h}$. All glassware with which zoospores came into contact was prewashed with $2 \mathrm{M}-\mathrm{HCl}$ overnight. Operations in which zoospores were transferred or mixed required care to minimize mechanical or pressure shock. Zoospores were exposed to the various ions in plastic tissue culture trays (Linbro, Conn., U.S.A.) for up to $120 \mathrm{~min}$. Unless stated otherwise the $\mathrm{pH}$ was 6.5 . When cyst populations were to be tested, they were induced from swimming zoospores by 2 min vigorous shaking (Tokunaga \& Bartnicki-Garcia, 1971). Cells were examined directly or after fixation with $2 \%$ glutaraldehyde, $\mathrm{pH} 6$. The numbers of cells and their developmental stage were determined using an inverted microscope with a calibrated grid in the ocular. A volume of $1.5 \mathrm{or} 2.0 \mathrm{ml}$ per chamber was used, and all incubations were carried out at $19 \pm 2{ }^{\circ} \mathrm{C}$. After fixation, cells were stable for at least a week at room temperature, but counting was always completed within $4 \mathrm{~d}$ of an experiment.

When the experimental procedure required that cells be transferred from one container to another, cells at different stages of development were not recovered with equal efficiency. Thus, the protocol was designed so that the entire experimental procedure could be carried out in one vessel. All experiments contained controls in which zoospores were held in $1 \mathrm{~mm}$ buffer during the period of treatment. All results are reported as percentages obtained from counts of 100-200 cells. Percentage encystment was calculated as: $100 \times$ (mean no. of encysted cells per field in test sample)/(mean no. of encysted cells per field in shaken sample). The percentage of encysted cells in the controls varied from one experiment to another but was usually in the region of $20 \%$. All allocations of treatments were made on the basis of random number tables (Fisher \& Yates, 1963) and the samples were counted blind.

It was possible to estimate the percentage of damaged cells by a direct count. However, the distinction between a damaged and an undamaged cell was not always clear-cut. Another method of assessing the viability of cells was to test their ability to germinate under optimal conditions. The addition of a mixture of $\mathrm{V} 8$ broth $(5 \%)$ and $\mathrm{Ca}^{2+}$ ( $4 \mathrm{~mm}$ ) was suitable for this purpose. The percentage of germinated cells was then used as an estimate of the viable cells in a population. All assays for viability were carried out at $22 \pm 2{ }^{\circ} \mathrm{C}$ for $180 \mathrm{~min}$, before the cells were killed by adding glutaraldehyde. Viability assays were carried out in the presence of the ionic species under test. It was shown in preliminary experiments that if the ions under test were added to swimming zoospores at the same time as the $\mathrm{Ca}^{2+} / \mathrm{V} 8$ medium only $\mathrm{Cs}^{+}$had any effect on germination: with $\mathrm{Cs}^{+}$at $50 \mathrm{~mm}$, germination was reduced from $98 \pm 1 \%$ to $92 \pm 2 \%$

\section{RES ULTS}

Three stages of zoospore development were distinguished.

1. Motile zoospores. After fixation, these were ovoid to elliptical in longitudinal view, and elliptical with a well-defined groove when viewed end on. No cell wall was visible and the cells had a clear or translucent appearance. Flagella were visible when the cells were viewed under phase-contrast or Nomarski interference microscopy. The cells appeared refractile under bright field microscopy.

2. Cysts or cystospores. These were round, with a clearly defined outline.

3. Germinated cysts. These cells had clearly visible germ tubes. However, some treatments gave rise to cyst papillae (Palzer, 1976; Ho \& Zentmyer, 1977). The cyst papillum appeared as a clearly defined swelling or protuberance on the surface of the cyst.

In addition, damaged cells were present after certain treatments. These were sometimes swollen, and lacked the clear outline of undamaged cells. Some treatments also induced a high proportion of lysed cells and cell fragments were visible. The extent of lysis was measured by the difference between the initial and the final cell concentration.

\section{Effect of temperature}

Both the viability and motility of zoospores were affected by temperature. The highest proportion of motile cells was maintained between $10^{\circ} \mathrm{C}$ and $20^{\circ} \mathrm{C}$, although even in this 


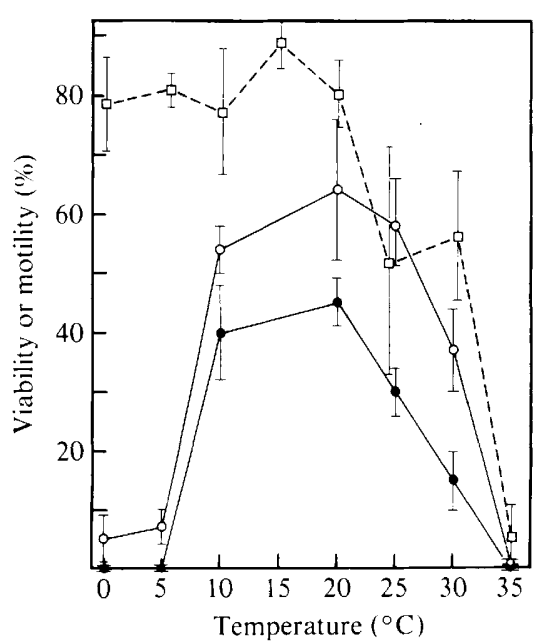

Fig. 1

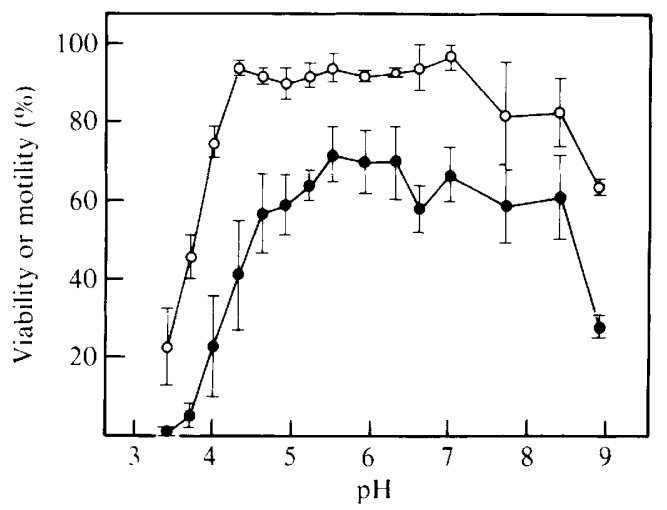

Fig. 2

Fig. 1. Effect of temperature on zoospores and cysts. Cell suspensions were held in $1 \mathrm{~mm}$-Tris-succinate buffer, $\mathrm{pH} 6$, for $2 \mathrm{~h}$ at the temperatures indicated before assay: cyst viability ( $\square$ ), zoospore viability (O) and motility (O). Results are expressed as the percentage of the total population which was viable or motile. The error bars represent \pm 1 s.D.

Fig. 2. Effect of $\mathrm{pH}$ on zoospore viability. Zoospore suspensions in $1 \mathrm{~mm}$-Tris-succinate buffer, $\mathrm{pH} 6$, were held for $30 \mathrm{~min}$ at $19^{\circ} \mathrm{C}$ at the $\mathrm{pH}$ values shown and then assayed for motility $(O)$ and viability (O).

temperature range a high proportion of cells encysted during the $2 \mathrm{~h}$ incubation period (Fig. 1). Below $10^{\circ} \mathrm{C}$ and above $25^{\circ} \mathrm{C}$ both the number of motile cells and the number of viable cells decreased rapidly. Temperature also affected the behaviour of the cells in more subtle ways. For example, above $25^{\circ} \mathrm{C}$, the zoospores were much more liable to encyst as a result of mechanical shock. Cyst populations were similar to zoospores in their response to temperatures above $25^{\circ} \mathrm{C}$. By contrast, cysts were much more resistant than zoospores to temperatures below $10^{\circ} \mathrm{C}$ (Fig. 1).

\section{Effect of $p H$}

Zoospores remained motile over the $\mathrm{pH}$ range $4 \cdot 5-8 \cdot 5$ and viability did not vary over this range. At the extremes of $\mathrm{pH}$, the number of motile zoospores fell markedly (Fig. 2). As the $\mathrm{H}^{+}$concentration increased above $10 \mu \mathrm{M}(\mathrm{pH}$ ), an increasing proportion of zoospores were immobilized. They rounded up, but only a small proportion (less than $30 \%$ at $\mathrm{pH} 4 \cdot 1$ ) formed cyst walls resistant to $1 \mathrm{M}-\mathrm{KOH}$. After exposure to $\mathrm{pH} 4 \cdot 1$ for $1 \mathrm{~min}$ the immobilized cells could not form alkali-resistant walls on shaking, nor when returned to $\mathrm{pH} 5.8$ and incubated for $30 \mathrm{~min}$. The response of cysts in viability tests at the extremes of $\mathrm{pH}$ was indistinguishable from that of zoospores.

\section{Effect of cations}

Zoospores of $P$. cinnamomi were affected by both the species of cation and its concentration. The effects observed ranged from transitory changes in swimming pattern to an increase in the rate of encystment and/or a decrease in the viability of cells. Here we report only the quantifiable effects on the transitions from zoospore to cyst and cyst to germinating cyst, as well as loss of viability. The rates at which ions induced changes in zoospores varied widely. Some ions, such as $\mathrm{K}^{+}$and $\mathrm{Ca}^{2+}$ acted rapidly: exposure to $\mathrm{K}^{+}(10 \mathrm{~mm})$ immobilized $80 \%$ of the zoospore population in $7 \mathrm{~min}$ and $\mathrm{Ca}^{2+}(25 \mathrm{~mm})$ had the same effect after $20 \mathrm{~min}$. 


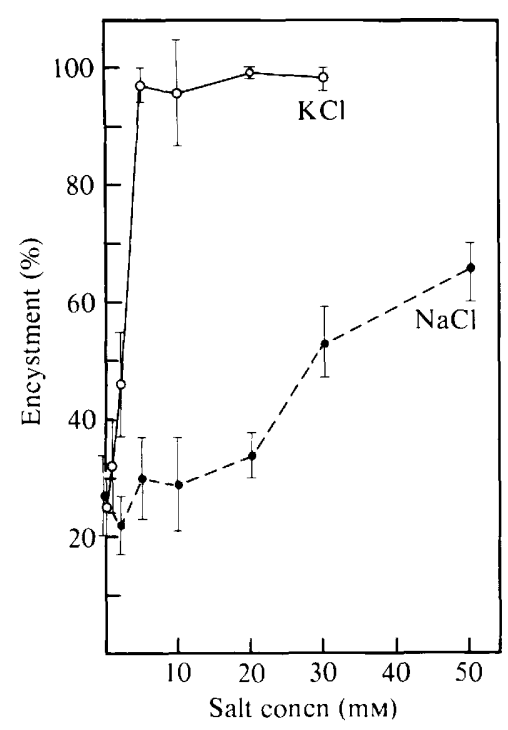

Fig. 3

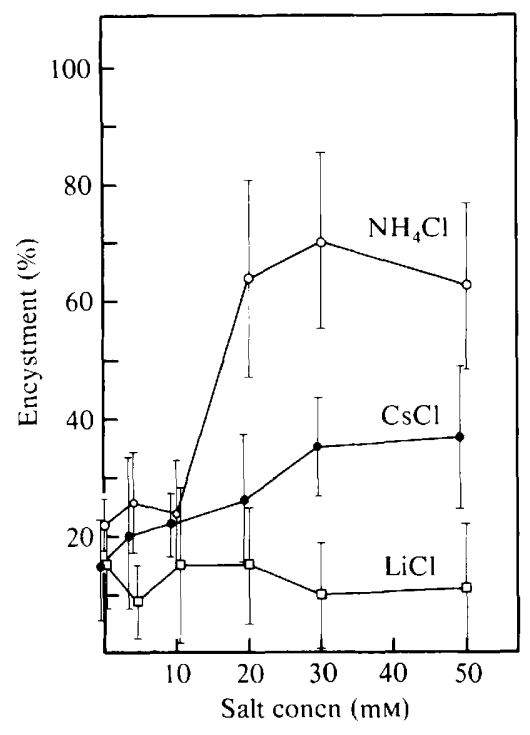

Fig. 4

Fig. 3. Effect of $\mathrm{KCl}(\mathrm{O})$ and $\mathrm{NaCl}(O)$ on zoospore encystment. Salts were added to zoospore suspensions to give the final concentrations indicated and the cells were fixed with glutaraldehyde after $20 \mathrm{~min}$ at $19^{\circ} \mathrm{C}$. No cell loss was detected in any sample.

Fig. 4. Effect of $\mathrm{NH}_{4} \mathrm{Cl}(\mathrm{O}), \mathrm{CsCl}(\mathrm{O})$ and $\mathrm{LiCl}(\square)$ on zoospore encystment. Conditions were as for Fig. 3 except that the incubation period was extended to $40 \mathrm{~min}$.

On the other hand, $\mathrm{Mg}^{2+}(25 \mathrm{~mm})$ acted much more slowly, requiring $90 \mathrm{~min}$ to immobilize $80 \%$ of the zoospores. $\mathrm{Na}^{+}$had a partial effect only, as exposure to $\mathrm{Na}^{+}(25 \mathrm{~mm})$ for $15 \mathrm{~min}$ immobilized $50 \%$ of the zoospore population but there was then no further immobilization in the next $45 \mathrm{~min}$.

The effect of various concentrations of $\mathrm{Li}^{+}, \mathrm{Na}^{+}, \mathrm{K}^{+}, \mathrm{Cs}^{+}$and $\mathrm{NH}_{4}{ }^{+}$on immobilization of the swimming zoospores is shown in Figs 3 and 4 . There were marked differences in the response to the different ions, with $\mathrm{Li}^{+}$at up to $50 \mathrm{~mm}$ inducing no encystment while $5 \mathrm{mM}-\mathrm{K}^{+}$induced essentially complete encystment. The order of effectiveness in the induction of encystment was $\mathrm{K}^{+}>\mathrm{NH}_{4}^{+}>\mathrm{Na}^{+}>\mathrm{Cs}^{+}>\mathrm{Li}^{+}$. The effect on viability was rather different (Fig. 5). Exposure to $\mathrm{K}^{+}$at $14 \mathrm{~mm}$ reduced viability to $60 \%$ but an increase in $\mathrm{K}^{+}$ concentration above this level did not decrease viability further. Exposure to $\mathrm{Na}^{+}, \mathrm{NH}_{4}^{+}, \mathrm{Li}^{+}$ and $\mathrm{Cs}^{+}$all resulted in a decrease in viability with increase in concentration.

Both $\mathrm{Cs}^{+}$and $\mathrm{NH}_{4}^{+}$treatments resulted in a high proportion of swollen and obviously damaged cells. The $\mathrm{Li}^{+}$treatment produced cells which had the appearance of motile zoospores but which moved only sluggishly, and these cells did not encyst or germinate on addition of $\mathrm{Ca}^{2+} / \mathrm{V} 8$ broth. The order of effectiveness of Group I cations in causing cell damage was $\mathrm{Cs}^{+}>\mathrm{Li}^{+}>\mathrm{K}^{+}>\mathrm{Na}^{+}$. The damage caused by $\mathrm{NH}_{4}^{+}$relative to the other monovalent cations tested was very dependent upon concentration. Below $10 \mathrm{~mm}, \mathrm{NH}_{4}{ }^{+}$had little effect on either motility or viability. However, at $50 \mathrm{~mm}$ it was second only to $\mathrm{K}^{+}$in causing immobilization and to $\mathrm{Cs}^{+}$in the reduction of viability of zoospore populations.

Cells incubated in solutions of mannitol or sorbitol at concentrations up to $100 \mathrm{~mm}$ did not show significant increases in the rates of encystment or decrease in viability. This, together with the differences in the effects of individual ions, makes it very unlikely that changes in osmotic pressure have a large effect on the processes observed. Even $\mathrm{NaCl}$, the salt least effective in inducing encystment, was more effective than mannitol or sorbitol. 


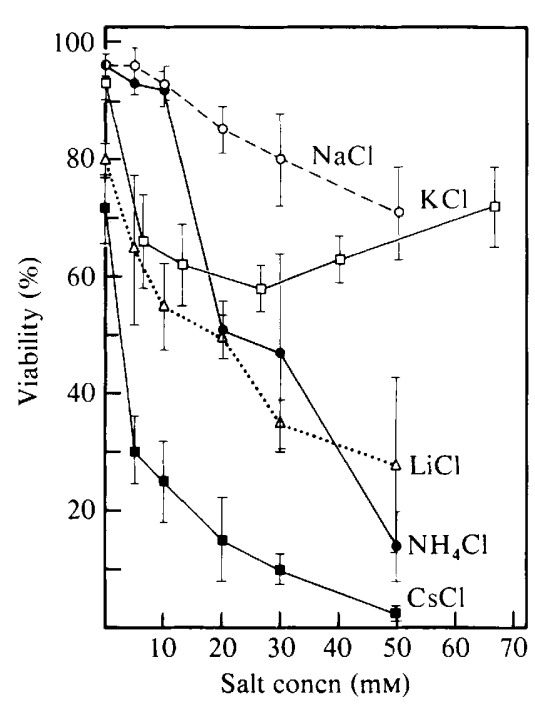

Fig. 5

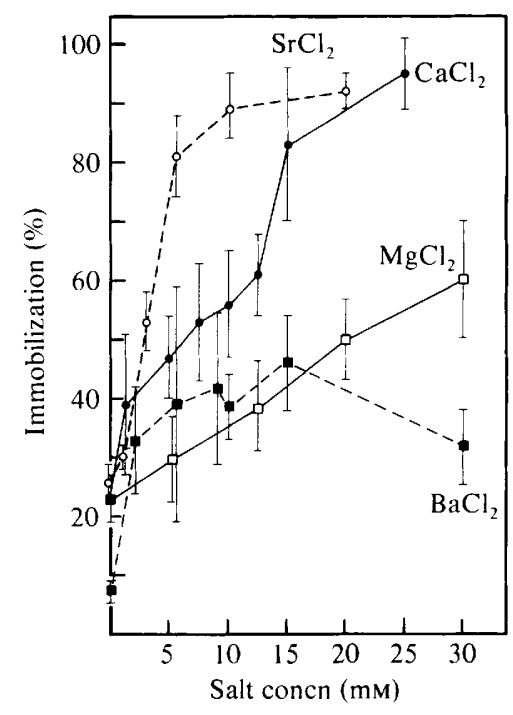

Fig. 6

Fig. 5. Effect of monovalent cations $\mathrm{K}^{+}(\square), \mathrm{Na}^{+}(\mathrm{O}), \mathrm{NH}_{4}^{+}(\mathrm{O}), \mathrm{Li}^{+}(\triangle)$ and $\mathrm{Cs}^{+}(\square)$ on zoospore viability. Conditions were as for Fig. 3 except that the incubation period was extended to $40 \mathrm{~min}$ for $\mathrm{Li}^{+}-$ and $\mathrm{Cs}^{+}$-treated samples. Viability was assessed following the addition of $\mathrm{Ca}^{2+} / \mathrm{V} 8$ and incubating at $24{ }^{\circ} \mathrm{C}$ for $3 \mathrm{~h}$. No cell loss was detected in any sample.

Fig. 6. Effect of divalent cations $\mathrm{Sr}^{2+}(\mathrm{O}), \mathrm{Ca}^{2+}(\mathbf{O}), \mathrm{Mg}^{2+}(\square)$ and $\mathrm{Ba}^{2+}(\square)$ on zoospore immobilization. Conditions were as for Fig. 4 except that $\mathrm{Mg}^{2+}$-treated samples were incubated for $90 \mathrm{~min}$ at $20^{\circ} \mathrm{C}$ prior to fixation. No cell loss was detected in $\mathrm{Ca}^{2+}, \mathrm{Sr}^{2+}$ - or $\mathrm{Ba}^{2+}$-treated samples, but loss occurred in the presence of $\mathrm{Mg}^{2+}$.

The effect of four divalent cations of Group IIA is shown in Fig. 6. All the ions in this series promoted encystment, with $\mathrm{Sr}^{2+}$ being the most effective. $\mathrm{Mg}^{2+}$, the least effective, required $90 \mathrm{~min}$ exposure before detectable effects could be observed. At this time cells were rounded and often swollen. Some of the cells retained reduced flagellar activity resulting in slow rotary motion. At a concentration of $10 \mathrm{~mm}$ the order of effectiveness in inducing encystment was $\mathrm{Sr}^{2+}>\mathrm{Ca}^{2+}>\mathrm{Ba}^{2+}, \mathrm{Mg}^{2+}$. Both $\mathrm{Ca}^{2+}$ and $\mathrm{Sr}^{2+}$ induced encystment without any cell damage, and in $\mathrm{Ca}^{2+}$ encystment was followed immediately by germination. The germination rate was higher in $\mathrm{Ca}\left(\mathrm{NO}_{3}\right)_{2}$ than in $\mathrm{CaCl}_{2}$ and this was one instance where the anionic species influenced the zoospore response. Germination did not immediately follow encystment after the addition of $\mathrm{Sr}^{2+}$ unless nutrient was added.

The trivalent cation $\mathrm{La}^{3+}$ has a similar ionic radius to $\mathrm{Ca}^{2+}$ and has been shown to act in a similar fashion in a number of biological systems although at lower concentrations (Takata $e t$ al., 1967). When $\mathrm{La}^{3+}$ was added to zoospore suspensions it was found that cells were immobilized at $0 \cdot 1-1 \mu \mathrm{M}$ almost immediately (Fig. 7). Cells which had been treated with $\mathrm{La}^{3+}$ were not viable, and at $\mathrm{La}^{3+}$ concentrations above $1 \mu \mathrm{M}$ there was complete lysis of the cell population. Therefore $\mathrm{La}^{3+}$ does not appear to act as an analogue of $\mathrm{Ca}^{2+}$ in this system, and mimics $\mathrm{Ca}^{2+}$ only to the extent of causing immediate immobilization.

$\mathrm{Fe}^{3+}$ and $\mathrm{Mn}^{2+}$ both induced encystment of the entire population of cells, $\mathrm{Fe}^{3+}$ at $15 \mu \mathrm{M}$ and $\mathrm{Mn}^{2+}$ at $500 \mu \mathrm{M}$. However, cells which encysted in the presence of these ions were completely viable, and thus $\mathrm{Fe}^{3+}$ and $\mathrm{Mn}^{2+}$ resembled $\mathrm{Ca}^{2+}$ and $\mathrm{Sr}^{2+}$ rather than $\mathrm{La}^{3+}$ in their effect. The trivalent cation $\mathrm{Al}^{3+}$ had no effect on either viability or encystment at the highest concentration tested $(30 \mu \mathrm{M}, \mathrm{pH} 5 \cdot 5)$.

Thus, $P$. cinnamomi zoospores were sensitive to all the cations tested. Different cations caused responses which differed both qualitatively and quantitatively and these are 


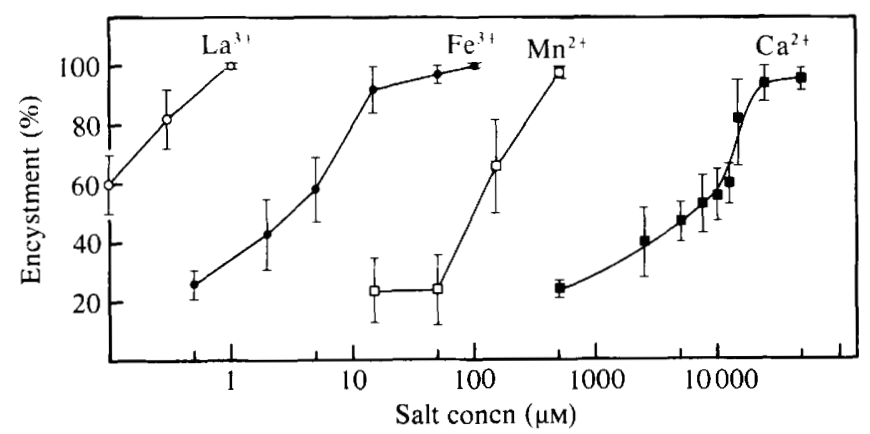

Fig. 7. Effect of $\mathrm{La}^{3+}(\mathrm{O}), \mathrm{Fe}^{3+}(\bigcirc), \mathrm{Mn}^{2+}(\square)$ and $\mathrm{Ca}^{2+}(\boldsymbol{\square})$ on zoospore encystment. Conditions were as for Fig. 3 except that the incubation period was extended to $30 \mathrm{~min}$ for $\mathrm{La}^{3+}, \mathrm{Fe}^{3+}-$ and $\mathrm{Mn}^{2+}$ and $40 \mathrm{~min}$ for $\mathrm{Ca}^{2+}$-treated samples.

Table 1. Summary of effects of inorganic cations on zoospores

$\begin{array}{lccc}\text { Cation } & \begin{array}{c}\text { Concn } \\ (\mathrm{mM})\end{array} & \begin{array}{c}\text { Immobilization } \\ (\%)\end{array} & \begin{array}{c}\text { Damage } \\ (\%)\end{array} \\ \text { Control } & - & 15 & 5 \\ \mathrm{La}^{3+} & 0 \cdot 001 & 100 & 75 \\ \mathrm{Fe}^{3+} & 0 \cdot 015 & 92 & 20 \\ \mathrm{Al}^{3+} & 0 \cdot 030 & <20 & <10 \\ \mathrm{H}^{+} & 0 \cdot 1 & 70 & 11 \\ \mathrm{Mn}^{2+} & 0 \cdot 5 & 98 & 27 \\ \mathrm{~K}^{+} & 5 & 95 & 30 \\ \mathrm{Ca}^{2+} & 20 & 90 & 5 \\ \mathrm{NH}_{4}^{+} & 30 & 85 & 50 \\ \mathrm{Mg}^{2+} & 30 & 50 & 60 \\ \mathrm{Na}^{+} & 30 & 35 & 20 \\ \mathrm{Li}^{+} & 30 & 20 & 65 \\ \mathrm{Cs}^{+} & 30 & 35 & 90 \\ & * \mathrm{Ca}^{2+} & & \end{array}$

summarized in Table 1. The trivalent cations, $\mathrm{Fe}^{3+}$ and $\mathrm{La}^{3+}$, were effective at concentrations several orders of magnitude lower than those required for the mono- and divalent cations, but $\mathrm{Al}^{3+}$ was without effect.

\section{Effect of anions}

In all of the experiments described above the $\mathrm{Cl}^{-}$salts were used, except in the case of $\mathrm{La}^{3+}$ in which the $\mathrm{NO}_{3}^{-}$salt was used. There was no difference between the $\mathrm{Cl}^{-}, \mathrm{NO}_{3}{ }^{-}, \mathrm{SO}_{4}{ }^{2-}$ and $\mathrm{PO}_{4}{ }^{3-}$ salts when $\mathrm{Na}^{+}$was the common cation (Table 2). Where there was an increase in the percentage of encystment it could be shown to be due to the variation in $\mathrm{Na}^{+}$concentration. Acetate, and to a lesser extent fluoride, reduced zoospore motility and viability.

\section{Effect of cations on cysts}

When cysts which had been induced to form by shaking were incubated in the presence of the various cations it was found that they were less sensitive than the swimming zoospores (Table 3). Only Cs ${ }^{+}$reduced the viability greatly, to $3 \%$ at $50 \mathrm{~mm}$. Both $\mathrm{K}^{+}$and $\mathrm{NH}_{4}^{+}$also reduced viability but none of the other ions tested had significant effects $(P=0.05)$. 
Table 2. Effect of various salts on zoospore encystment and viability

Values are the means of five replicates \pm standard deviation.

$\begin{array}{lccc}\text { Addition } & \begin{array}{c}\text { Concn } \\ (\mathrm{mM})\end{array} & \begin{array}{c}\text { Encystment } \\ \text { at } 60 \text { min (\%) }\end{array} & \begin{array}{c}\text { Viability } \\ \text { at } 60 \text { min (\%) }\end{array} \\ \mathrm{Control} & - & 16 \pm 5 & 95 \pm 4 \\ \mathrm{NaCl} & 20 & 18 \pm 7 & 91 \pm 7 \\ \mathrm{NaCl} & 40 & 79 \pm 7 & 64 \pm 12 \\ \mathrm{NaNO}_{3} & 20 & 39 \pm 11 & 91 \pm 4 \\ \mathrm{Na}_{2} \mathrm{SO}_{4} & 20 & 74 \pm 11 & 70 \pm 8 \\ \mathrm{NaH}_{2} \mathrm{PO}_{4} / \mathrm{Na}_{2} \mathrm{HPO}_{4}, \mathrm{pH} 6 & 20 & 51 \pm 15 & 88 \pm 7 \\ \mathrm{NaF} & 20 & 33 \pm 7 & 67 \pm 8 \\ \mathrm{Na}\left(\mathrm{CH}_{3} \mathrm{COO}\right), \mathrm{pH}^{6.8} & 20 & 94 \pm 12 & 48 \pm 14 \\ \mathrm{KCl}_{\mathrm{NH}} \mathrm{Cl}_{\mathrm{CaCl}} & 20 & \mathrm{ND} & 56 \pm 10 \\ & 20 & \mathrm{ND} & 45 \pm 16 \\ & 20 & 100 \pm 12 & 96 \pm 2\end{array}$

Table 3. Effect of cations on cyst viability

Cysts were exposed for $40 \mathrm{~min}$ at $19^{\circ} \mathrm{C}$.

$\begin{array}{lcr}\text { Addition } & \begin{array}{c}\text { Concn } \\ (\mathrm{mM})\end{array} & \begin{array}{c}\text { Viability } \\ (\%)\end{array} \\ \text { Control } & - & 84 \pm 6 \\ \mathrm{Na}^{+} & 50 & 80 \pm 7 \\ \mathrm{~K}^{+} & 50 & 58 \pm 7^{*} \\ \mathrm{Li}^{+} & 50 & 68 \pm 10 \\ \mathrm{Cs}^{+} & 50 & 3 \pm 3^{*} \\ \mathrm{NH}_{4}^{+} & 50 & 62 \pm 4^{*} \\ \mathrm{Ca}^{2+} & 30 & 100 \pm 3 \\ \mathrm{Mg}^{2+} & 30 & 97 \pm 3 \\ \mathrm{Sr}^{2+} & 30 & 80 \pm 4 \\ \mathrm{Ba}^{2+} & 30 & 90 \pm 2\end{array}$

* Significant at level $P=0.05$.

\section{DISCUSSION}

Our results showing the sensitivity of $P$. cinnamomi zoospores to cations resemble those described by Svensson \& Unestam (1975) for zoospores of the biflagellate Oomycete Aphanomyces astaci, although it is difficult to make direct comparisons as those authors did not distinguish quantitatively between encystment and germination. They found that $\mathrm{LiCl}$ and $\mathrm{CsCl}$ were toxic, that zoospores were more sensitive to $\mathrm{KCl}$ than to $\mathrm{NaCl}$, and that germination rates were highest in the presence of $\mathrm{CaCl}_{2}$. They concluded that the initiation of germination was partly due to an osmotic effect on the zoospores as mannitol and mannose were also effective. However, in their work, as in ours, mannitol was less effective than $\mathrm{NaCl}$, and much less effective than $\mathrm{KCl}$ or $\mathrm{CaCl}_{2}$, and it seems more likely that specific ion effects were involved.

Soll \& Sonneborn (1972) also concluded that ion effects on the monoflagellate Blastocladiella emersonii zoospores were not due to osmotic shock, as sucrose had no effect in their system. In many respects, however, the ion selectivity patterns observed with $B$. emersonii differed significantly from those for biflagellates. $\mathrm{K}^{+}, \mathrm{Na}^{+}, \mathrm{Cs}^{+}$and $\mathrm{Rb}^{+}$salts were all found to elicit encystment and germination of $B$. emersonii zoospores, although $\mathrm{Li}^{+}$was found to be toxic. $\mathrm{Ca}^{2+}$ and $\mathrm{Mg}^{2+}$ were less effective and germ tubes formed in response to $\mathrm{Ca}^{2+}$ appeared to be defective, and $\mathrm{NH}_{4}{ }^{+}$ions had little effect. 
Soll \& Sonneborn (1972) performed their experiments in the presence of low concentrations of other ions, and low concentrations of ions are thought to be essential for motility of both monoflagellate and biflagellate zoospores (Cameron \& Carlile, 1980). In our experiments, no attempt was made to exclude low concentrations of ions either carried over as leachate from the washed mycelium or from the glass containers in which mycelium and zoospores were held. Therefore, we would expect that low concentrations of ions, in the micromolar range, would be present at all times. Such concentrations are apparently sufficient to maintain the motility and viability of $P$. cinnamomi zoospores. At the higher ion concentrations tested in our work, the effect of $\mathrm{Ca}^{2+}$ was unique. Although both $\mathrm{Sr}^{2+}$ and $\mathrm{K}^{+}$were more effective in inducing encystment, only $\mathrm{Ca}^{2+}$ triggered encystment followed by germination. Although our experiments do not point to any mechanism, they suggest that $\mathrm{Ca}^{2+}$ may well play a specific role in nature in the developmental cycle of this fungus.

It is well established that cations interact with biological membranes at concentrations comparable with those used in the present studies (Williams, 1972). The ability to distinguish between closely similar ions and molecules is a basic function of cell membranes. A similar selectivity is also shown in a range of non-biological systems. It has been shown that the relative order of activity of the alkali cations and cations of higher valencies with many biological and non-biological systems is restricted to a few sequences. These include the Hoffmeister lyotropic series and are related to the field strength of the ions under different conditions (Diamond \& Wright, 1969). Thus, it may be predicted that if the effects of cations on zoospores involved a direct interaction of cation with anionic plasmalemma, the relative order of cation activity would correspond to one of these sequences.

The relative order of activity of the alkali cations on encystment was $\mathrm{K}^{+}>\mathrm{Na}^{+}>\mathrm{Cs}^{+}>$ $\mathrm{Li}^{+}$which is either sequence V or VI of Diamond \& Wright (1969). However, the order of effectiveness in causing cell damage did not correspond to any of the 11 possible sequences. Neither did the order of activity of the divalent cation series on encystment or viability correspond to any of the sequences proposed by Diamond \& Wright (1969) for these ions, and the effects of $\mathrm{Ca}^{2+}$ differed qualitatively as well as quantitatively from the other divalent ions.

It is known that Phytophthora zoospores are repelled by many inorganic cations (Allen \& Harvey, 1974; Cameron \& Carlile, 1980). This negative chemotactic response occurs at different threshold concentrations for each cation. Comparison of our results with the studies on negative chemotaxis shows that for some cations, e.g. $\mathrm{H}^{+}, \mathrm{Na}^{+}, \mathrm{K}^{+}, \mathrm{Li}^{+}$and $\mathrm{Ca}^{2+}$, the threshold concentration for inducing negative chemotaxis is close to the minimum concentration for inducing a detectable effect, either encystment or cell damage. For $\mathrm{Mg}^{2+}$ and $\mathrm{La}^{3+}$ there is no correspondence, $\mathrm{Mg}^{2+}$ being less effective and $\mathrm{La}^{3+}$ more effective in our system.

For the monovalent cation series, the negative chemotactic response follows the Hoffmeister lyotropic series for cation exchange reactions. Therefore, a general mechanism to explain the phenomenon of negative chemotaxis has been suggested whereby cations interact with the negatively charged zoospore membrane. This reduces the negative charge, thus altering the transmembrane potential and changing flagellar activity (Cameron \& Carlile, 1980). However, our data and also that of Cameron \& Carlile (1980) for divalent cations indicates that superimposed on such a general ion-membrane interaction there are specific ion effects. This is to be expected, as it is known that, even where binding constants are similar, different cations modify membrane structure in different ways (Williams, 1972; Papahadjopoulos et al., 1979). Beyond this there is the further situation of site-specific binding of which that of $\mathrm{Ca}^{2+}$ has been most intensively studied (Whitfield et al., 1980).

The studies reported in this paper also have practical implications. Although it is hazardous to extrapolate from the laboratory to the field, the results do suggest that soil cation content could influence the behaviour of $P$. cinnamomi zoospores directly. In soils with high $\mathrm{K}^{+}, \mathrm{Ca}^{2+}, \mathrm{Mg}^{2+}, \mathrm{Mn}^{2+}$ or $\mathrm{Fe}^{3+}$ levels, the cells would not remain in the motile stage for long and this, in turn, could influence the rate of dispersion. The levels of the above cations 
required to induce encystment are in the range of concentrations reported for soil solutions (Nye $\dot{\&}$ Tinker, 1977), although the levels of $\mathrm{NH}_{4}{ }^{+}$required for any effect on zoospore behaviour would not be expected in natural waters. Failure of $\mathrm{Al}^{3+}$ to produce any effect on zoospore motility or viability argues against this ion playing a role in the disease distribution, although it has been shown that this ion does limit mycelial growth of the related P. capsici (Muchovej et al., 1980).

Although high cation levels reduce the viability of motile zoospores, once encystment has taken place in the absence of these cations the cells are more resistant to their effects. The results also show that zoospores of $P$. cinnamomi have a broad tolerance to $\mathrm{pH}$. Only the extremes of the acid or alkaline range observed in soil might be expected to inhibit zoospore development. Similarly, zoospores and cysts tolerate a broad range of temperatures, although surface soil temperatures might be expected to exceed $25^{\circ} \mathrm{C}$ and fall below $10^{\circ} \mathrm{C}$, the limits of tolerance, on many occasions. Here too, the cyst stage displays a greater tolerance of low temperatures than the motile stage, although a different spore form, the chlamydospore, is the survival stage of this organism.

This work was supported in part by grants from the Victorian Forests Commission and from the Potter Foundation to B.R.G. P.N.B. was supported by a Commonwealth Postgraduate Research Award.

\section{REFERENCES}

Allen, R. N. \& Harvey, J. D. (1974). Negative chemotaxis of zoospores of Phytophthora cinnamomi. Journal of General Microbiology 84, 28-38.

Bimpong, C. E. \& Clerk, G. C. (1970). Motility and chemotaxis in zoospores of Phytophthora palmivora (Butl.) Butl. Annals of Botany 34, 617-624.

Bimpong, C. E. \& HiCKMAN, C. J. (1975). Ultrastructural and cytochemical studies of zoospores, cysts and germinating cysts of Phytophthora palmivora. Canadian Journal of Botany 53, 13101327.

Boughton, T. J., Malajczuk, N. \& Robson, A. D. (1978). Suppression of the infection of jarrah roots by Phytophthora cinnamomi with application of calcium carbonate. Australian Journal of Botany 26, 611-615.

BroAdBENT, P. \& BAKER, K. R. (1974). Behaviour of Phytophthora cinnamomi in soils suppressive and conducive to root rot. Australian Journal of Agricultural Research 25, 121-137.

Byrt, P. N. \& Grant, B. R. (1979). Some conditions governing zoospore production in axenic cultures of Phytophthora cinnamomi Rands. Australian Journal of Botany 27, 103-115.

Cameron, J. N. \& Carlile, M. J. (1980). Negative chemotaxis of zoospores of the fungus Phytophthora palmivora. Journal of General Microbiology 120, 347-353.

DiAmond, J. M. \& Wright, E. M. (1969). Biological membranes: the physical basis of ion and nonelectrolyte selectivity. Annual Review of Physiology 31, 581-646.

Fisher, R. A. \& YATEs, F. (1963). Statistical Tables for Biological, Agricultural and Medical Research, 6th edn. Edinburgh: Oliver and Boyd.
Halsall, D. M. \& Forrester, R. I. (1977). The effects of certain cations on the formation and infectivity of Phytophthora zoospores. I. Effects of calcium, magnesium, potassium and iron ions. Canadian Journal of Microbiology 23, 994-1001.

Hemmes, D. E. \& HoHL, H. R. (1971). Ultrastructural aspects of encystment and cyst germination in Phytophthora parasitica. Journal of Cell Science $\mathbf{9}$, 175-191.

Ho, H. H. \& Zentmyer, G. A. (1977). Morphology of Phytophthora cinnamomi. Mycologia 69, 701-713.

LUNNEY, C. Z. \& Bland, C. E. (1976). Ultrastructural observations of mature and encysting zoospores of Pythium proliferum de Bary. Protoplasma 90, 119-137.

MuchoveJ, J. J., Maffia, L. A. \& MuchoveJ, R. M. C. (1980). Effect of exchangeable soil aluminium and alkaline calcium salts on the pathogenicity and growth of Phytophthora capsici from green pepper. Phytopathology 70, 1212-1214.

NyE, P. H. \& Tinker, P. B. (1977). Solute Movement in the Soil-Root System. Oxford: Blackwell Scientific Publications.

PAlzer, C. (1976). Zoospore inoculum potential of Phytophthora cinnamomi. Ph.D. thesis, University of Western Australia.

Papahadjopoulos, D., Poste, G. \& Vail, W. J. (1979). Studies on membrane fusion with natural and model membranes. Methods in Membrane Biology 10, 1-121.

Sing, V. O. \& Bartnicki-Garcia, S. (1975). Adhesion of Phytophthora palmivora zoospores: electron microscopy of cell attachment and cyst wall fibril formation. Journal of Cell Science 18, 123132.

Soll, D. R. \& SONNEBoRn, D. R. (1972). Zoospore 
germination in Blastocladiella emersonii. IV. Ion control of cell differentiation. Journal of Cell Science 10, 315-333.

Svensson, E. \& Unestam, T. (1975). Differential induction of zoospore encystment and germination in Aphanomyces astaci, Oomycetes. Physiologia plantarum 35, 210-216.

Takata, M., Pickard, W. F., Lettvin, J. Y. \& MOORE, J. W. (1967). Ionic conductance changes in lobster axon membrane when lanthanum is substituted for calcium. Journal of General Physio$\log y$ 50, 461-471.

Tokunaga, J. \& Bartnicki-Garcia, S. (1971). Cyst wall formation and endogenous carbohydrate utilization during synchronous encystment of Phytophthora cinnamomi zoospores. Archiv für Mikrobiologie 79, 283-292.

Whitfield, J. F., Boynton, A. C., Macmanus, J. P., Rixon, R. H., Sikorska, M., Tsang, B., Walker, P. R. \& Swieranga, S. H. H. (1980). Role of calcium and cyclic AMP in cell proliferation. Annals of the New York Academy of Sciences 339, 216-240.

Williams, R. J. P. (1972). A dynamic view of biological membranes. Physiological Chemistry and Physics 4, 427-439. 